\title{
The Competitiveness of China's Honey in Target International Markets Compared with Argentina
}

\author{
Haiying Song \\ School of International Business Admin istration \\ Zhejiang International Studies University \\ Hangzhou, China \\ e-mail: haiyingsong@hotmail.com
}

\author{
Helen H. Jensen \\ Department of Economics \\ Iowa State University \\ Ames, US \\ e-mail: hhjensen@iastate.edu
}

\begin{abstract}
Honey is a significant product in China's production, consumption, and export. Determining the competitiveness of China's honey in international markets is important for understanding honey's relative position in China's agriculture and the development for its agribusiness firms. The objective of this paper is to measure the competitiveness of honey from China compared with that of Argentina in the target markets of the United States (US), Japan, and European Union (EU). We use four indices to assess the competitiveness: the Target Market $S$ hare (TMS), Unit Import Price (UIP), Quality Competition Index (QCI), and Regional Revealed Symmetric Comparative Advantages (RRSCA). China's honey is less competitive than honey from Argentina in the US and EU markets. Increased domestic demand, appreciation of the Chinese Yuan (CNY) and governmental trade policies are among factors that have affected the global honey trade.
\end{abstract}

Keywords-competitiveness; honey; target market; China; Argentina

\section{INTRODUCTION}

China leads the world in honey production. It has increased its share of world output from $19.98 \%$ in 2001 to $28.35 \%$ in $2012^{1}$. Expansion of per capita honey production is in line with China's National 12th Five-year Plan for Beekeeping. At the same time, the share of domestic sales for China's honey has expanded dramatically from $36.71 \%$ in 2001 to $79.62 \%$ in 2010 of the total output and the share of honey available for export has fallen during the same period. Argentina has become a major competitor to China in world honey market and is now the leading supplier to world markets, providing almost $24 \%$ of g lobal honey. Competition between China and Argentina is fierce, especially in the key target markets of the United States (US), Japan and the European Union $(\mathrm{EU})^{2}$.

This article's main objective is to analyze the competitiveness of China compared with Argentina in the global honey market. Determination of the relative competitiveness for both countries supports the analys is of

\footnotetext{
${ }^{1}$ Honey in this paper is defined as natural honey, which HS code in database is 0409. Data source: FAOSTAT, http://faostat fao.org/

${ }^{2}$ The target markets of China's honey are defined as US, Japan and EU because they are the largest three economies for China's honey exporting Their total share to the world accounts to $86.25 \%$ in 2012 . Data source: UN comtrade.
}

specific factors that affect the countries' respective advantage in different markets. The factors have implications for the relative competitiveness in trade going forward and strategies the countries' might use to enhance their competitiveness. Sharples (1990) defines competitiveness as the ability to survive and increase market share. Examining various measures of competitiveness allows us to incorporate the advantages and disadvantages of the specific methods in the assessment. Among the measures, we consider the aggregate approach of Revealed Comparative Advantage index. Other measures more directly incorporate production costs, product quality, and marketing effectiveness (Parker et al., 2001).

The global honey market has come under increasing scrutiny. In 2007, the U.S. International Trade Commission (2007) issued a report on their investigation of honey imported from Argentina and China. They found that China's honey fared less well than honey from Argentina in the US market in terms of market share and quality. Other studies have found that the relative competitiveness depends on the measures used and period of time assessed. Gu and Zhang (2003) find Argentina's honey to be more competitive than that of China in world market based on measures of Revealed Comparative Advantage and an index of comprehensive competitiveness. Using an index of Regional Revealed Symmetric Comparative Advantage, Ying and Zhou (2005) find China's honey to have an export advantage in the US market, however its relative advantage is decreasing and Argentina has become a major competitor. $\mathrm{Li}$ and $\mathrm{Wu}$ (2009) reach similar conclusions based on indices of Market Share, Revealed Symmetric Comparative Advantage, and Comprehensive Competence. They find the comprehensive competitiveness of China's honey to be now weaker than that of Argentina. Liu and Liu (2012) use current trade patterns for China's honey to analyze its comparative advantage in world markets and find that honey from China has a strong comparative advantage based on measures of price, international market share and Revealed Symmetric comparative advantage.

Our study makes several contributions to the available literature. Although various indices have been used to measure competitiveness in the honey market, none can be identified as a "best" measure; each measure has a specific economic implication. Also, although many comparisons 
have been done on the competitiveness in the honey market between China and Argentina, most do not direct their analys is to the competitiveness in one or two specific target markets. Instead, the studies consider trade from the perspective of the global market. Finally, most of the previous studies use data from 2008 or earlier. However, many changes have occurred in the patterns of honey trade since the collapse of the world economy in 2008. Recent changes in global markets, as well as China's own situation have affected the competitiveness of honey from China today. The use of updated data and analysis of influential factors to analyze honey's competitiveness in major trading markets can better inform an understanding of competitiveness in honey markets today. Therefore, we address three questions:

a) Is China's honey less competitive than that of Argentina in the target markets of US, Japan, and EU?

b) What is the source of any competitive advantage in the different target markets? What accounts for the fluctuation in competitiveness of China's honey in the target markets?

c) What are the implications from a change in the competitiveness of honey from China under the identified influential factors for policy and for agribusiness development?

A set of appropriate indicators is developed to compare honey's competitiveness between China and Argentina from the perspective of target markets using the latest available data. The evidence presented provides effective reference and suggestions for policymakers and related businesses.

The structure of this article is as follows. After this introductory section, the second section deals with the methods used for calculating indicators of competitiveness. The third section presents the results from measuring the competitiveness in target markets. The fourth section compares measures of competitiveness and factors associated with fluctuation in the competitiveness of China's honey. The final section provides main conclusions.

\section{METHODOLOGY OF MEASURING COMPETITIVENESS}

In addressing the concept of international competitiveness and measures of competitiveness, it is important to note that the choice of any specific index for best measuring competitiveness depends on the question and specific aspect of trade competitiveness of interest. Four indices are useful as measures for the evaluation of the competitiveness of China and Argentina in honey from the target markets' perspective: Target Market Share, Unit Import Price, Quality Competition Index, and Regional Revealed Symmetric Comparative Advantages Index.

\section{A. Target Market Share}

Target Market Share (TMS) is the ratio of import value fro m one country to total import value from all countries in the target market. Many economists mention that market share is the most direct indicator for measuring competitiveness (Li and Liu, 2012). TMS takes on a value between 0 and 1; the larger the TMS, the more competitive is the product in the target market. If TMS is greater than 0.20 (more than 20\%), the product (honey) from this country would be found to show strong competitiveness; share values between $5 \%$ to $20 \%$ indicate some degree of competitiveness; and values less than 5\% indicate no competitiveness in the market.

\section{B. Unit Import Price}

The Unit Import Price (UIP) measure includes a price or value component is a useful addition to measuring competitiveness. The UIP is the unit price of import value divided by net weight of product traded. It provides a measure of comparative advantage in the target market. The lower the UIP, the more competitive in the market is the country exporting the product, and vice versa. The use of quantity (net weight of product traded) in the UIP measure itself provides some advantage in comparison to the TMS measure. Although market opportunity can be obtained through a low unit price, a low UIP also indicates low profit and may suggest product dumping. This may lead the importing country to assert injuries on its domestic industry. The United States has accused China of dumping in the honey market and imposed anti-dumping charges and related duties (Bottemiller, 2013).

\section{Quality Competition Index}

The Quality Competition Index (QCI) extends the measures of competitiveness by accounting for quality differences. It is measured as the ratio of a country's unit import price index divided by the average import price index of total target market. An increase of QCI incorporates the contribution of increases in value-added and also reflects improvement in quality. In contrast, a decrease in the QCI indicates a drop in perceived quality. The QCI is calculated as:

$$
Q C I=\frac{P_{i t} / P_{i 0}}{P_{m t} / P_{m 0}}
$$

where $Q C I$ is the quality competition index; $P_{i t}$ is import price of country $i$ in year $t ; P_{i 0}$ is import price of country $i$ in a selected base year; $P_{m t}$ is the average import price of target market in year $t$; and $P_{m 0}$ is the average import price of target market in the selected base year. The year of 2000, which is the year that just precedes China's accession to the World Trade Organization (WTO), is chosen here to be the base year.

\section{Regional Revealed Symmetric Comparative Advantages Index}

The Regional Revealed Symmetric Comparative Advantages (RRSCA) index captures differences in product heterogeneity and can be used to provide a more comprehensive measure when product differences reflect basic product heterogeneity. The RRSCA reflects several revisions to the Revealed Comparative Advantage Index (RCA) measure (Ying and Zhou, 2005) and is calculated as:

$$
\operatorname{RRSCA}=\frac{\left(X_{i c} / X_{t c}\right) /\left(X_{i w} / X_{t w}\right)-1}{\left(X_{i c} / X_{t c}\right) /\left(X_{i w} / X_{t w}\right)+1}
$$


where $X_{i c}$ is the export value of honey from country $c$ to the target market; $X_{t c}$ is total export value of all commodities from country $c$ to the target market; $X_{i w}$ is total import value of honey from the world to the target market; and $X_{t w}$ is total import value of all commodities fro $m$ the world to the target market.

The value of the RRSCA lies between -1 and 1 . A value of $0.85 \leq \mathrm{RRSCA} \leq 1$ shows the product has an absolute advantage in the target market; $0.5 \leq \mathrm{RRSCA} \leq 0.85$ indicates strong advantage; $0 \leq \mathrm{RRSCA} \leq 0.5$ indicates weak advantage; $-0.5 \leq \mathrm{RRSCA} \leq 0$ indicates weak disadvantage; $0.85 \leq$ RRSCA $\leq-0.5$ shows obvious disadvantage; and $0.85 \leq \mathrm{RRSCA} \leq-1$ represents absolute disadvantage.

Among the above four indices (TMS, UIP, QCI, and RRSCA), there is a progressive relationship in the various measures of competitiveness. However, each measures a different aspect of competitiveness. TMS only indicates market share through trade value. The UIP further compares the price advantage of honey from different countries. However, measuring competitiveness on unit price alone may not be sufficient owing to the potential for low profits and trade barriers. The QCI is an indicator of value-added, but it is only partly reflects competitiveness when there is underlying product heterogeneity. The RRSCA is more comprehensive and reflects the competitive power of the traded product from different countries. It is widely used by World Bank and other international organizations. The use of the four measures provides an integrated observation on the nature of the competitiveness, here, the competitiveness of China's honey exports compared with those from Argentina.

Data on honey trade from China and Argentina to the US, Japan and EU are obtained from the United Nations (UN) (Comtrade) ${ }^{3}$ and US Department of Agriculture (USDA) ${ }^{4}$. Data from Comtrade are available from the 1990s to the latest year. The National Honey Report from United States Department of Agriculture (USDA) provides more detailed data on different categories of honey imported from all countries by the United States.

\section{COMPETITIVENESS IN TARGET MARKETS}

\section{A. Competitiveness in the Market of US}

The gap between the honey import value from China and Argentina in the US market has grown dramatically during recent years. Value of honey imported from Argentina by the United States was $\$ 127.98$ million in 2012 compared with a value of only $\$ 0.06$ million from China. The import value of Argentina's honey in the US market has increased every year since 2004. The import

\footnotetext{
${ }^{3}$ The website is http://comtrade.un .org/ In order to promote the comparability, import data from China and Argent ina in target markets from China and Argentina are used because the stat istical value of exported goods is an FOB-type (Free On Board) value and the statistical value of imported goods is a CIF-type (Cost, Insurance and Freight) value. The import value is more comparable than export one because of different distance between China and Argent ina to the target markets. Different distance means different insurance and freight.

${ }^{4}$ National honey report from Agricultural Marketing Service Fruit and Vegetable Programs Market News Division of United States Department of Agriculture. The website is www.ams.usda.gov/mnreports/fvmhoney.pdf
}

value of 2012 is more than 17 times as large as that of 2004. In contrast, the import value of China's honey in US market has decreased during the same period.

Historically, the United States has always been an important target market for China's honey. Owing to the surge of honey imported from China prior to 2000, the United States pursued a strategy to diversify its market sources to reduce trade risks. The number of import sources for honey increased from 33 countries in 1998 to 58 countries in 2010 . China has not been among the top five countries for imports of honey to the US honey market since 2007. More recently, since 2005 Argentina has taken a leading role as one of the top three importing countries into the US honey market.

\section{1) Target Market Share}

The proportion of China's honey in US market is much smaller than that of Argentina in terms of market share (TMS) and the gap between them has become larger since 2004, as shown in Table I . Why has the market share of China's honey in US fallen? Masked in the aggregate measure of market share is the shift in product categories. After 2007, the leading type of honey from China shifted from extra light amber honey (2007) to white honey (2008 to 2011) and flavored honey in 2012. The shifting composition of honey from China has been an important factor influencing the decrease in China's market share.

TABLE I. COMPETITIVENESS OF CHINA AND ARGENTINA IN THE USHONEY MARKET

\begin{tabular}{ccccccccc}
\hline \multirow{2}{*}{ Year } & \multicolumn{3}{c}{ TMS (\%) } & \multicolumn{2}{c}{ UIP (\$/kg) } & \multicolumn{2}{c}{ QCI } & \multicolumn{2}{c}{ RRSCA } \\
\cline { 2 - 9 } & China & Argentina & China & Argentina & China & Argentina & China & Argentina \\
2000 & 26.06 & 47.79 & 0.94 & 1.02 & 1.00 & 1.00 & 0.68 & 0.99 \\
2002 & 5.01 & 10.78 & 1.12 & 2.14 & 0.68 & 1.20 & -0.11 & 0.95 \\
2004 & 22.54 & 5.00 & 1.25 & 2.07 & 0.77 & 1.17 & 0.42 & 0.91 \\
2006 & 16.07 & 25.72 & 0.94 & 1.67 & 0.72 & 1.17 & 0.15 & 0.98 \\
2008 & 3.20 & 13.00 & 0.66 & 3.00 & 0.34 & 1.42 & -0.36 & 0.96 \\
2010 & 0.86 & 18.26 & 1.70 & 3.20 & 0.72 & 1.25 & -0.96 & 0.98 \\
2012 & 0.01 & 29.76 & 3.20 & 3.01 & 1.19 & 1.04 & -1.00 & 0.99 \\
\hline
\end{tabular}

Source: database of UNCOMT RADE.

\section{2) Unit Import Price}

From the perspective of price alone, China's honey holds a competitive advantage to that of Argentina in the US market. As shown in Table I, the unit prices of China's honey are lower than those of Argentina during the period of 2000-2010. It should be noted that the nature of unit price advantage is that it reflects low revenue. The relatively low unit price of China's honey in the US market reveals the challenge for China's exporters in generating profit compared to Argentina's - especially when accompanied by the relative decrease in export quantity. Another phenomenon which should be noted is that the unit price of China's honey in US market has been quite a bit more volatile than that of Argentina.

\section{3) Quality Competition Index}

In terms of quality, China's honey does not compare favorably to that of Argentina in the US market. Since 2000 , there have been only three years where the quality index of China's honey (QCI) was above that of the base year in 2000 (see Table I ). Relative to 2000, the valueadded of China's honey has decreased for much of the last decade. In contrast, the quality of Argentinean honey in the US market has been uniformly strong (Table I ). 


\section{4) Regional Revealed Symmetric Comparative}

Advantages Index

From the perspective of RRSCA index, China's honey in the US market has fared much worse than that of Argentina. The RRSCA of Argentinean honey in the US market has been greater than 0.85 during the 2000 to 2012 period, a result which indicates that there is an absolute advantage for Argentinean honey in US market. In contrast, the RRSCA of China's honey in the US market has decreased throughout the period and become negative since 2007, even less than -0.85 since 2009 - indicating an absolute disadvantage for China's honey in the US market.

\section{B. Competitiveness in the Market of Japan}

Japan has always been the largest target market for China's honey exports. Behind China, Argentina has often been the second largest country in terms of import share to the Japanese honey market. Since the 2005-07 periods, both Chinese and Argentinean exports of honey have increased in the Japanese market. By 2012, the value of China's honey imported by Japan was $\$ 63.12$ million, compared with only $\$ 7.33$ million for Argentina. During the period of 2000 to 2010 , the average annual growth rate of Argentinean honey in the Japanese market was 51.99\% compared to only $10.14 \%$ for China's honey during the same period.

With a relatively long history of trade and the importance of China's honey to the Japanese market, both China and Japan attach great importance to their mutual honey trade and the imports of Chinese honey has represented an expanding proportion in Japanese total honey consumption ${ }^{5}$. A Regular Communicating Mechanism has been established to handle honey trade frictions. Producers, beekeepers, traders, and government officials hold bilateral meetings on honey annually to discuss trade and other issues. Many problems related to trade, such as antibiotic residues, have been settled through mutual communication. Within this environment, honey imports from China in Japanese market have steadily increased.

TABLE II. COMPETITIVENESS OF CHINA AND ARGENTINA IN THE JAPANESE HONEY MARKET

\begin{tabular}{|c|c|c|c|c|c|c|c|c|}
\hline \multirow{2}{*}{ Year } & \multicolumn{2}{|c|}{ TMS (\%) } & \multicolumn{2}{|c|}{ UIP (\$/kg) } & \multicolumn{2}{|r|}{ QCI } & \multicolumn{2}{|c|}{ RRSCA } \\
\hline & China & Argent ina & China & Argent ina & China & a Argentina & China & Argent ina \\
\hline 2000 & 84.33 & 4.32 & 0.89 & 1.14 & 1.00 & 1.00 & 0.77 & 0.96 \\
\hline 2002 & 77.30 & 8.74 & 1.10 & 1.56 & 0.96 & 1.07 & 0.73 & 0.98 \\
\hline 2004 & 71.42 & 7.84 & 1.10 & 2.38 & 0.87 & 1.45 & 0.59 & 0.98 \\
\hline 2006 & 80.44 & 5.79 & 1.37 & 1.75 & 0.96 & 0.95 & 0.69 & 0.98 \\
\hline 2008 & 72.30 & 7.42 & 1.75 & 2.82 & 0.93 & 1.17 & 0.65 & 0.99 \\
\hline 2010 & 65.52 & 10.34 & 2.03 & 3.34 & 0.88 & 1.13 & 0.60 & 0.98 \\
\hline 2012 & 59.90 & 6.95 & 2.19 & 3.31 & 0.83 & 0.98 & 0.55 & 0.96 \\
\hline
\end{tabular}

\section{1) Target Market Share}

Fro $m$ the perspective of market share, the proportion of China's honey in the Japanese market is much larger than that of Argentina. However, Ch ina's relative advantage has decreased. As shown in Table II, the TMS of China's

\footnotetext{
${ }^{5}$ The rat io of import honey in total domestic consumption is $31.51 \%$ in 1993 , which accounts for $62.99 \%$ in 2010 . Dat a source: FAOSTAT, http://faostat.fao.org/
}

honey in Japanese market in 2000 was as high as $84.33 \%$ and has decreased to $60 \%$ by 2012 . Except for 2010 , Argentina's TMS has been below 10\% during the same period.

\section{2) Unit Import Price}

From the perspective of price, honey from China's has remained more competitive than Argentina in the Japanese market. The UIP measure indicates that China's honey has been lower in price than that of Argentina during the 20002012 periods. The price gap between them is more than $\$ 1$ per kilogram since 2008 shown in Table II . Just as in the US market, low unit price contributes to low revenue. The UIP for both Chinese and Argentinean honey has increased in the Japanese market during the period.

\section{3) Quality Competition Index}

Comparison of the QCI shows that honey from Argentina fares better than that of China during the 20002012 period in the Japanese market. The QCI of Argentina's honey in Japan has been near or above the base year during the period of 2000-2012. By contrast, since 2002, China has been below the base year of 2000 . By this measure, the value-added of Argentinean honey is relatively higher than that of China in the Japanese market.

\section{4) Regional Revealed Symmetric Comparative} Advantages Index

By the RRSCA index measure, China's measure is in the range of 0.50 and 0.85 for the period while Argentina index measures in the range of 0.85-1.0. From the perspective of regional revealed symmetric comparative advantage, the measures indicate that although China's honey has a strong advantage in trade in the Japanese market, Argentina holds an absolute advantage.

\section{Competitiveness in the Market of EU}

The total honey import value from China in the EU market has been larger than that of Argentina in recent years and the level of Chinese exports to the EU market have increased markedly since 2007. The honey import value from China to the EU market was \$ 118.61 million in 2011; the value of Argentinean honey fell to only $\$ 56.14$ million in $2012^{6}$.

There are 27 member countries in EU and only 7 of them imported honey from China in 2004. However, by 2007 , the number of countries importing honey from Ch ina increased to 12 and increased further to 21 by 2011. The increased number of countries importing from China explains a large part of the increase in value during the period. Among the countries in the EU, the United Kingdom imports the largest amount of honey from China (25.18\% of the total import value in 2011). The second and third largest country importing China's honey is Belgium and Poland, respectively. During this period, there was some shift in the EU imports from Argentina to China.

\section{1) Target Market Share}

From the perspective of market share, until 2010, the proportion of China's honey in the EU market has been lower than that of Argentina, as shown in Table III. However, China' market share has increased steadily since 2005. During the period 2000-2012, the average TMS of

\footnotetext{
${ }^{6}$ Trade value of 2012 may be a bit lower than the reality because data of honey import value from some EU members are not available yet. Data source: database of UNCOMT RADE.
} 
China's honey in EU market was only $7.46 \%$ in comparison to an average of $17.92 \%$ for Argentinean honey during the same period. By 2012, China's market share was $19 \%$ compared to only $9.56 \%$ for Argentina.

TABLE III. COMPETITIVENESS OF CHINA AND ARGENTINA IN THE EU HONEY MARKET

\begin{tabular}{|c|c|c|c|c|c|c|c|c|}
\hline \multirow{2}{*}{ Year } & \multicolumn{2}{|c|}{ TMS (\%) } & \multicolumn{2}{|c|}{ UIP (\$/kg) } & \multicolumn{2}{|r|}{ QCI } & \multicolumn{2}{|c|}{ RRSCA } \\
\hline & China & Argent in & China & Argent i & China & Argentina & China & Argent ina \\
\hline 2000 & 12.30 & 19.20 & 0.77 & 1.01 & 1.00 & 1.00 & 0.73 & 0.98 \\
\hline 2002 & 3.96 & 21.51 & 1.02 & 1.44 & 0.86 & 0.93 & -0.06 & 0.98 \\
\hline 2004 & 0.29 & 18.97 & 1.17 & 2.26 & 0.65 & 0.95 & -0.95 & 0.98 \\
\hline 2006 & 2.60 & 23.42 & 1.19 & 1.52 & 0.89 & 0.86 & -0.26 & 0.98 \\
\hline 2008 & 6.14 & 18.03 & 1.69 & 2.50 & 0.84 & 0.95 & 0.17 & 0.98 \\
\hline 2010 & 11.94 & 12.12 & 1.70 & 2.97 & 0.79 & 1.05 & 0.28 & 0.96 \\
\hline 2012 & 19.00 & 9.56 & 1.86 & 2.90 & 0.91 & 1.07 & 0.41 & 0.95 \\
\hline
\end{tabular}

\section{2) Unit Import Price}

From the perspective of price, China's honey market is more competitive in the EU market than that of Argentina. As shown in Table III, the unit import price of China's honey in EU market has been lower than that of Argentina during the period of 2000-2012 and the gap between the prices for the two has been larger since 2005, which has been more than \$1 per kilogram since 2009.

\section{3) Quality Competition Index}

For the EU, neither the Chinese nor the Argentinean honey shows an advantage in the EU market. However, since 2010, the QCI of Argentinean honey in the EU market is higher than that of the base year, a result that suggests some improvement in perceived quality in the market. However, in general, the QCI measure shows that the value-added of exported honey both from China and from Argentina in the EU market has been relatively constant and not any better than that observed in 2000 .

4) Regional Revealed Symmetric Comparative Advantages Index

From the perspective of regional revealed symmetric comparative advantage, China's honey in the EU market lags behind that of Argentina. The RRSCA of Argentinean honey in the EU market has been more than 0.85 since 2000 , which indicates that there is absolute advantage for Argentinean honey in the market. Although the RRSCA index was between 0.5 and 0.85 for China's honey in the EU market in 2000 and 2001, implying a strong advantage for China's honey, the index has been below 0.5 since then It should be mentioned that the RRSCA of China's honey in the market of the EU has increased each year since 2005, a result which indicates strengthening of China's position in the EU market.

\section{FACTORS AFFECTING THE CHANGES OF COMPETITIVENESS}

Although the four methods of assessing the competitiveness of honey in international markets can complement each other, it is inevitable that the results may be contradictory. The results show that based on the calculation of TMS, China's honey may be more or less competitive than that of Argentina among different target markets of US, Japan, and EU. However, Ch ina's honey is more competitive (stronger) in the targeted markets compared with that of Argentina when measured through the index of UIP and less competitive (weaker) co mpared with that from Argentina based on the QCI and RRSCA measures. We have examined the potential reasons for the lower price of China's honey in different markets. However, why is China's honey less competitive than that from Argentina based on the synthetic QCI and RRSCA indices in all target markets? Some common factors are as follows.

\section{A. Domestic Demand in China}

Apart from exporting honey to foreign countries, more and more China's honey is produced for domestic consumption. China is the largest country in the world by population with an estimated 1.3 billion citizens and has one of the world's fastest growing economies (Brosch, 2013). The ratio of domestic honey consumption to production was $16.94 \%$ in 1992 , and increased to $79.62 \%$ by 2010 . Per capita consumption of honey in China is approximately 300 grams, as reported in China's National 12th Five-year Plan of Beekeeping. However, even in 2009 , honey was not available for consumers in some cities and rural areas ${ }^{7}$. In contrast, per capita consumption of honey for the consumers of developed economies is much higher. The U.S. per capita consumption of honey is around 1.3 pounds (or 590 gram) per year ${ }^{8}$. As incomes increase, consumers pay greater attention to health and nutritional aspects of food products. Within China, honey consumption is expected to increase as honey is viewed as being rich in nutrition. The export of China's honey will face increasing pressure from domestic demand.

This increasing tendency of honey consumption in the domestic market has also been emphasized by China's trading companies. More of them choose to sell honey to the domestic market rather than export to avoid the inherent risks of differences in languages, laws, and cultures. The pressure from domestic markets for honey will decrease the export of China's honey, and will further reduce the competitiveness of China's honey compared with that of Argentina. Along with the issue raised by concerns on China's non-market based status, the road for China's honey to be exported to the US becomes more difficult. All the results of indices in measuring China's honey competitiveness show a loss of competitive power in the US market.

\section{B. Shifting Exchange Rate}

The fluctuation of exchange rates will greatly impact competitiveness. Recently, the Chinese Yuan (CNY) has appreciated against most other world currencies. Hence, the international competitiveness of export product has been weakened.

Under the pressures from US and Japanese governments and domestic Purchasing Power Parity (PPP) and Balance Of international Payment (BOP), the appreciation of CNY is inevitable. The average exchange rate of one USD exchanging into CNY is steadily shifting from 8.28 in 2000 to 6.30 in $2012^{9}$. The relative price of

\footnotetext{
${ }^{7}$ Ministry of Agricultural of the People's Republic of China. China's National $12^{\text {th }}$ Five-year Plan of Beekeeping. December 27 of 2010 . In Chinese.

${ }^{8}$ Dat a source: website of US National Honey Board, www.honey.com/ 9 Data source: http://www.oanda.com/
} 
China's exported honey has increased through the appreciation of the CNY and the competitiveness of China's honey has weakened. Although the value of exported honey and its competitiveness have not fallen because of other factors that are favorable, the appreciation of the CNY has made trade more difficult and led many exporting firms in China to avoid exporting honey to foreign markets.

In comparison, the average exchange rate of one USD to the Argentine Peso (ARP) was 2.92 in 2004, and increased to 4.54 in 2012. This depreciation of ARP to USD has served to improve the competitiveness of Argentinean honey in the world market.

\section{Government Trade Policies}

During the accession to the WTO, China has made a promise of no export subsidy on agricultural products, a commitment which applies to honey as well. Chinese government just asks honey industrial firms to improve safety and quality without financial support. In contrast, Argentinean honey has benefited from three kinds of support from the government to enhance its competence.

First is support on coping with trade issues. During the 1990s, antibiotic residues appeared on Argentinean honey in the US and EU markets. The Argentinean government put forward many countermeasures, such as research on acceptable drugs for bees and training for beekeepers on how to improve technology and drug use. In addition, the government established an advanced system of quality monitoring to ensure the safety of honey. Second, the Ministry of Agriculture and state government in Argentina started a promotion program to help finance and support beekeepers. This program encouraged beekeepers to set up and join associations to avoid vicious competition on the exporting price to gain more profits. Third, the government provided subsidies on honey exports. Dealers could get $10 \%$ subsidy from Argentinean government in honey export (Li and Liu, 2012).

\section{CONCLUSIONS}

Although honey is viewed often as only as a byproduct of pollination, it plays an important role in China both in meeting growing internal use as well as for export. However recently, China has faced increasing competition in honey trade from Argentina in its three target markets: the US, Japan, and EU. Various measures of competitiveness can shed light on the changes that have occurred in trade over the last two decades. We used the measures of Target Market Share (TMS), Unit Import Price (UIP), Quality Competition Index (QCI), and Regional Revealed Symmetric Comparative Advantages (RRSCA) to assess the competitiveness of China's honey compared with Argentina. The results show that China's honey is more competitive in terms of UIP and less competitive based on the QCI and RRSCA measures in all of its target markets. In contrast, China's honey is disadvantaged in the US market under the TMS measure because of anti-dumping provisions that have an effect on the trade. At the same time, China has gained a larger market share in the Japanese honey market compared to Argentina. This growing advantage may be explained by the occurrence of annual bilateral meetings for beekeepers, processors, and government officials. After suffering setbacks in 2002 due to food safety and quality concerns, China's honey has been gaining advantage in the EU market as it has improved its level of food safety and quality and gained the confidence of EU consumers. Three factors can potentially deteriorate the synthetic competitiveness of China's honey: the surge of domestic demand of honey with the increasing per capita income, the appreciation of $\mathrm{CNY}$, and increasing support from Argentinean government to its honey industry.

\section{ACKNOWLEDGMENT}

This research was financially supported by National Natural Science Foundation of China (Grant NO. 71303222).

\section{REFERENCES}

[1] Sharples, J. A. (1990). Cost of Production and Productivity in Analyzing Trade and Competitiveness. American Journal of Agricultural Economics, 72, 1278.

[2] Parker, D., Chaudhary, N., \& Duering, A. (2001). Competition for World Honey Markets: An Alberta Perspective. Alberta Agriculture, Food and Rural Development.

[3] U.S. International Trade Commission (2001, June). Honey from Argentina and China, Investigation Nos. 701-T A-402 and 731-T A892 and 893, Publication 3929.

[4] Gu, G. \& Zhang, C. (2003). Analysis on Chinese honey export competitiveness. Chinese Rural Economy, 7, 60-64, 80.

[5] Ying, R. \& Zhou, L. (2005). Analysis on Regional Revealed Symmetric Comparative Advantage of Chinese Honey Export. International Trade Journal, 8, 41-46.

[6] Li, H. \& Wu, J. (2009). Comparative Analysis on the International Competitiveness of China Honey Trade. Journal of International Trade, 10, 26-31.

[7] Liu, Q. \& Liu, J. (2012). Analysis on Comparat ive Advantages and Influencing Factors of Chinese Natural Honey. International Business, 5, 13-22.

[8] Li, G. \& Liu, J. (2012). Empirical Analysis of International Competitiveness of China's Industry after a Decade of WTO Accession. Finance \& Trade Economics, 8, 88-96.

[9] Bottemiller, H. (2013). "Honey gate" Sting Leads to Charges for Illegal Chinese Honey Importation, Food Safety News, February 26. http://www.foodsafetynews.com/2013/02/honeygate-stingleads-to-charges-for-illegal-chinese-honey-importation/

[10] Li, H. \& Liu, W. (2012). Analysis on Domestic and Foreign Beekeeping Policies, Apiculture of China, 5, 43-46. 